\title{
Airway hyperresponsiveness in asthma: lessons from in vitro model systems and animal models
}

\author{
H. Meurs, R. Gosens and J. Zaagsma
}

ABSTRACT: Airway hyperresponsiveness (AHR) is a hallmark clinical symptom of asthma. At least two components of AHR have been identified: 1) baseline AHR, which is persistent and presumably caused by airway remodelling due to chronic recurrent airway inflammation; and 2) acute and variable AHR, which is associated with an episodic increase in airway inflammation due to environmental factors such as allergen exposure.

Despite intensive research, the mechanisms underlying acute and chronic AHR are poorly understood. Owing to the complex variety of interactive processes that may be involved, in vitro model systems and animal models are indispensable to the unravelling of these mechanisms at the cellular and molecular level.

The present paper focuses on a number of translational studies addressing the emerging central role of the airway smooth muscle cell, as a multicompetent cell involved in acute airway constriction as well as structural changes in the airways, in the pathophysiology of airway hyperresponsiveness.

KEYWORDS: Airway hyperresponsiveness, airway inflammation, airway pharmacology, airway remodelling, airway smooth muscle, animal models of asthma

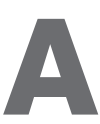
llergic asthma is a chronic inflammatory disease of the airways. Characteristic features of this disease are allergen-induced early and late bronchial obstructive reactions, airway inflammation, structural changes to the airway wall associated with progressive decline in lung function, and airway hyperresponsiveness (AHR) [1]. AHR is defined by an exaggerated obstructive response of the airways to a variety of pharmacological, chemical and physical stimuli, including histamine, methacholine, AMP, sulphur dioxide, fog and cold air [2,3]. AHR is a risk factor for the development of asthmatic symptoms in children and adults, is associated with the severity of respiratory symptoms and decline in lung function, and determines the need for therapy [3].

Despite intensive research, the mechanisms of AHR are only partially understood. The complex variety of interactive processes that appear to be involved in the pathophysiology of AHR urges detailed in-depth investigations aimed at unravelling the underlying mechanisms at the cellular and molecular level in relation to their functional significance and hence at identifying potential targets for drug therapy. Since there are obvious ethical and experimental limitations, these mechanisms cannot be simply investigated in human subjects; therefore, in vitro model systems and animal models are indispensable. The present review focuses on a number of translational paradigms using these model systems, particularly addressing the role of the airway smooth muscle cell, not only as the key determinant of airway narrowing in asthma but also as an emerging effector of airway inflammation and remodelling [4-11].

\section{VARIABLE AND CHRONIC AHR}

It has been recognised that there are at least two components of AHR, the mechanisms of which

\section{AFFILIATIONS}

Dept of Molecular Pharmacology, University Centre for Pharmacy, Groningen, The Netherlands.

\section{CORRESPONDENCE}

H. Meurs

Dept of Molecular Pharmacology University Centre for Pharmacy

Antonius Deusinglaan 1

NL-9713 AV Groningen

The Netherlands

Fax: 31503636908

E-mail: h.meurs@rug.nl

Received:

February 142008

Accepted:

February 182008

\section{SUPPORT STATEMENT}

R. Gosens is the recipient of a Veni grant (No. 916.86.036) from the Netherlands Organisation for Scientific Research (The Hague, The Netherlands)

STATEMENT OF INTEREST None declared. 
may be different [12]. The first component is baseline and relatively persistent $\mathrm{AHR}$, which is present in the majority of patients with chronic asthma. Superimposed on this, there is a component of variable AHR, which can be induced by episodic exposure to environmental factors, such as allergens or respiratory tract infections $[13,14]$. The variable component of AHR presumably reflects current airway inflammation associated with asthma activity and severity [15, 16], whereas the underlying chronic component of AHR probably relates to structural alterations in the airways collectively called airway remodelling [12].

Airway remodelling is characterised by persistent structural changes to the airway wall, including epithelial denudation, goblet cell metaplasia, subepithelial fibrosis, increased airway smooth muscle mass, angiogenesis and alterations to extracellular matrix components [17-19]. It is generally believed that both airway remodelling and chronic AHR may be induced by chronic or prolonged airway inflammation [12]. However, the causal relationship between these factors in patients with asthma has recently been challenged. Thus indices of airway remodelling may already be evident in childhood asthma, with no obvious relationships to asthma symptoms and airway inflammation [20-23]. This has led to the concept that inflammation and airway remodelling may occur as parallel rather than sequential events. This concept might fit with the hypothesis that an intrinsic inability of appropriate repair of epithelial injury in response to environmental agents in genetically susceptible individuals activates the epithelial-mesenchymal trophic unit, leading to the secretion of a variety of growth factors, mediators and cytokines by the activated airway epithelium, which drives the airway remodelling and promotes persistent airway inflammation [24]. In addition, the causal relationship between AHR and airway remodelling is uncertain [25]. Thus, although increased airway smooth muscle mass and function as well as structural changes to the airways may well explain an increase in airway responsiveness [4, 6, 26-29], airway remodelling could also be protective in limiting excessive airway narrowing by means of increased stiffening of the airways [28, 30, 31].

The relationship between variable AHR and inflammation of the airways seems rather well established. For allergic asthma, this is indicated by numerous studies demonstrating a direct association between allergen-induced acute changes in airway responsiveness and type-2 T-helper cell (Th)-driven eosinophilic airway inflammation, as well as its sensitivity to antiinflammatory therapy [12]. Nevertheless, there is some evidence that acute AHR and eosinophilic airway inflammation may dissociate. Thus treatment with anti-interleukin (IL)-5 and antiimmunoglobulin (Ig) E did not affect allergen-induced AHR despite reduced blood and airway eosinophil numbers [32]. However, the results of this study should be interpreted with caution [33]. Changes in airway geometry caused by both mucosal and adventitial swelling of the airways due to oedema could theoretically play a role in allergen-induced AHR, amplifying the degree of luminal narrowing for a given degree of airway smooth muscle shortening and mechanically uncoupling the airway smooth muscle from the parenchyma, respectively [34, 35]. However, even though mucosal thickening has smaller effects on airway resistance than on airway responsiveness [35], allergen-induced AHR persists after airway calibre has fully returned to baseline [36]. Moreover, AHR develops after challenge with low subclinical doses of allergen without significant change in pulmonary function [37, 38]. Therefore, inflammation-induced alterations in the control of airway smooth muscle function are likely to be of major importance. These changes could involve changes in the neurohumoral control of airway smooth muscle tone as well as changes in the airway smooth muscle cell itself, altering its responsiveness to external stimuli [39-43]. However, clinical evidence for such mechanisms is scarce and this area obviously requires further exploration.

\section{IN VITRO MODEL SYSTEMS AND ANIMAL MODELS}

In vitro model systems utilising human or animal (particularly bovine and guinea pig) primary airway smooth muscle cells and airway smooth muscle tissue preparations are widely used in studies on AHR, and have been particularly useful in unravelling molecular mechanisms of contractile, proliferative and synthetic cell function, as well as their pharmacological modulation [6, 8, 40, 42, 44-48]. Airway smooth muscle tissue from asthmatic subjects permitting contraction studies or cell culture is scarce, and the limited number of studies performed thus far have delivered inconsistent results regarding the responsiveness of these preparations to contractile and relaxant agonists $[42,49,50]$. Interestingly, cultures of airway smooth muscle cells from endobronchial biopsy specimens from asthmatic patients have been described recently, demonstrating intrinsic differences between asthmatic and nonasthmatic cells, with increased proliferative and synthetic capacities of the asthmatic cells [50-53].

Small animal models of asthma, using mice, rats and guinea pigs, have proven to be extremely useful for the investigation of potential mechanisms of airway pathophysiology in the intact organism in vivo, as well as in isolated organs and cells ex vivo [54-58]. Likewise, animal models have been indispensable for the identification of a vast number of potential drug targets, as well as for efficacy and safety testing of new drugs. Nevertheless, there are appreciable interspecific differences in airway physiology and pathophysiology between the various animal models of asthma, as well as between animal models and human asthmatics, that should be taken into account when studying particular phenotypes of the disease.

Currently, the most widely used experimental animal for modelling allergic responses in the airways is the mouse, particularly because of the availability of trangenic and genetargeted animals, as well as the variety of commercially available mouse-specific immunological tools for phenotypic and functional analysis of cells and mediators. Mouse models of allergic asthma have proved to be very useful in the investigation of mechanisms of allergic inflammation and the underlying immunological response that are believed to be important in a variety of processes in allergic asthma, including development of AHR [55, 58]. Mice are easily sensitised to a number of antigens, including ovalbumin and human allergens, such as house dust mite and Aspergillus fumigatus. Intraperitoneal sensitisation and subsequent inhalational challenge with these antigens results in a clearly defined Th2 response in the airways, characterised by the development of antigen-specific IgE, eosinophilia and AHR, which may, however, vary considerably between strains [58]. Similarly, 
repeated antigen challenge induces airway remodelling in this species, which, depending on strain and/or sensitisation and challenge protocols, may or may not be associated with chronic AHR [59-62]. In this regard, the house dust mite model developed by JOHNSON et al. [59] is of particular interest. In contrast to ovalbumin models, this model permitted sensitisation via the natural route without the development of immunological tolerance, whereas airway remodelling and AHR induced by repeated allergen challenge persisted after cessation of allergen exposure and resolution of airway inflammation.

However, murine models appear to be less well suited to the investigation of the mechanisms of acute hyperresponsiveness in relation to early and late asthmatic responses. Thus AHR and early asthmatic reactions are usually observed only after repeated allergen challenge, and a late asthmatic reaction is rarely observed [58, 63]. Difficulties in measuring these physiological responses could be related to the anatomical structure of the mouse lung, which is characterised by relatively large airways and a paucity of airway smooth muscle and mucous glands in the airways [58, 64]. In addition, because of its small size, lung function measurement is a significant challenge in the mouse, a situation which has widely favoured the use of noninvasive barometric plethysmography in conscious mice for the measurement of enhanced pause (Penh) [65]. Penh is an empirical variable derived from respiratory variations in box pressure with no direct linkage to established mechanical parameters, which has recently been seriously questioned as a valid measure of lung function [66, 67]. Another drawback of measuring physiological as well as pharmacological responses in mice is the unresponsiveness of airway smooth muscle to various bronchoconstrictors implicated in the pathophysiology of asthma, including histamine, cysteinyl leukotrienes, neurokinins, bradykinin and prostanoids [54]. Moreover, as in rats, the primary mediator of allergen-induced bronchoconstriction is serotonin, not histamine, and inhibitory nonadrenergicnoncholinergic (iNANC) nerves are absent in these species [54]. However, in contrast to mice, rat models of allergic asthma, particularly of the Brown Norway strain, develop, usually modest, IgE-mediated early and late asthmatic reactions upon allergen challenge, which are associated with Th2-directed eosinophilic airway inflammation and hyperresponsiveness that is usually measured 18-24 h after challenge. Moreover, repeated allergen challenge causes airway remodelling, including airway smooth muscle hyperplasia and subepithelial fibrosis [56].

From both a physiological and pharmacological point of view, sensitised guinea pigs may be preferable as an animal model for investigating mechanisms of early and late asthmatic reactions and AHR in asthma [54, 57, 58, 68-71]. For example, measurements in conscious and unrestrained animals demonstrate allergen-induced early and late asthmatic reactions, eosinophilic airway inflammation and AHR following both the early and the late reaction with a striking similarity to that seen in human allergic asthma, in both a qualitative and a quantitative sense $[57,70]$. In addition, compared with rodents such as mice and rats, airway smooth muscle responsiveness and autonomic reflexes in guinea pigs more closely resemble those of human airways [54,69]. Furthermore, various features of airway remodelling have been observed after repeated allergen challenge [72-74], which have been associated with AHR ex vivo [73]. From a technical point of view, disadvantages of the guinea pig as an experimental animal may be the nonavailability of genetically modified animals and the relative scarcity of immunological tools for this species, although the latter circumstance is rapidly improving.

\section{ACUTE MODULATION OF AHR}

\section{Nitric oxide and arginase}

Nitric oxide (NO) is a ubiquitous molecule in mammalian species, serving as a signalling molecule that is involved in the control of almost every cellular and organ function in the body, including the airways $[75,76]$. In the respiratory tract, isoforms of constitutive NO synthase (NOS; cNOS) are mainly expressed in iNANC neurons (neuronal NOS (nNOS)), the endothelium (endothelial NOS (eNOS)) and the epithelium (nNOS and eNOS), which are primarily involved in the regulation of airway and vascular smooth muscle tone [7678]. Moreover, eNOS-derived NO has been shown to inhibit airway inflammation by suppressing the activation of nuclear factor- $\kappa \mathrm{B}$, thereby inhibiting the expression of inducible NOS (iNOS), as well as the production of inflammatory cytokines [79-82]. In inflamed asthmatic airways, there is marked upregulation of iNOS expression, particularly in epithelial and inflammatory cells, including macrophages, eosinophils and neutrophils [76, 83, 84], which is associated with greatly increased production of $\mathrm{NO}$ and increased concentrations of NO in exhaled air [76, 85]. In experimental asthma, iNOS is induced in the airways during the allergen-induced late asthmatic reaction, leading similarly to increased levels of $\mathrm{NO}$ in exhaled air [86, 87]. High concentrations of iNOSderived NO have been considered to be detrimental in the airways since they contribute to increased vascular permeability, mucus hypersecretion, inflammatory cell infiltration, epithelial cell damage and perpetuation of the Th2-mediated inflammatory response in the airways [76]. Most if not all of the deleterious effects induced by iNOS-derived NO may proceed via formation of peroxynitrite $\left(\mathrm{ONOO}^{-}\right)$, a highly reactive oxidant synthesised by the rapid reaction of $\mathrm{NO}$ with superoxide anion $\left(\mathrm{O}_{2}^{-}\right)$, generated in the inflamed airways [88, 89]. Significant correlations between exhaled $\mathrm{NO}$ level, airway eosinophilia and AHR have been observed in asthmatics, whereas all of these parameters are reduced after glucocorticosteroid treatment [89-92]. Based on these observations, the NO concentration in exhaled air has been adopted as a sensitive marker of airway inflammation [93]. Therefore, it is not surprising that much of the literature regarding $\mathrm{NO}$ in asthma has long been focused on iNOS and is heavily biased towards a harmful pro-inflammatory role of NO. However, given the variety of enzymatic and cellular sources of NO in the airways, the different cellular targets and physiological effects of $\mathrm{NO}$, as well as the influence of the local microenvironment on $\mathrm{NO}$ homeostasis, the relevance of increased exhaled NO levels to discrete pathophysiological processes in the airway wall may be difficult to determine. Indeed, various studies in animal models and patients have now indicated that AHR and inflammation of the airways is caused by failure of both cNOS- and iNOSderived NO to exert bronchodilatory and anti-inflammatory effects rather than by an excess of NO [94]. 
In a guinea pig model of acute allergic asthma, in the absence of iNOS expression, which is induced during the late asthmatic reaction or by chronic allergen exposure in this model, it was demonstrated that the exhaled NO level is transiently increased immediately after allergen challenge, followed by a fall to below control levels [95]. The decrease in NO production could well contribute to the early asthmatic reaction, as well as to the ensuing AHR. Indeed, both in vivo and ex vivo studies using the same species indicate that a deficiency of both epithelial and neuronal cNOS-derived NO underlies the development of AHR following the allergen-induced early asthmatic reaction (fig. 1) [77, 96, 97]. A deficiency of cNOS activity and endogenous bronchodilating NO contributing to AHR was also demonstrated after repeated allergen challenge of sensitised guinea pigs [98, 99]. Importantly, it was demonstrated that a reduction in cNOS-derived NO may also contribute to AHR in patients with severe asthma [100], and may similarly be induced by allergen exposure [101]. Interestingly, decreased cNOS (presumably iNANC)-derived NO could also contribute to reduced bronchoprotection by means of deep inspiration in asthmatic patients, which has been recognised as an important factor contributing to AHR [102-105].

Various mechanisms have been implicated in allergen-induced NO deficiency. Reduced expression of eNOS or nNOS has been observed after repeated allergen challenge in guinea pigs and mild asthmatic patients, respectively $[101,106]$. In addition, it has been demonstrated that reduced bioavailability of Larginine, the substrate for NOS, may underlie the deficiency in NO and subsequent AHR [96, 107]. Animal studies have indicated that polycationic proteins, including eosinophilderived major basic protein (MBP), inhibit cellular uptake of Larginine by cationic amino acid $\mathrm{y}^{+}$transporters [108], which may contribute to the deficiency in cNOS-derived NO and AHR after the early asthmatic reaction $[109,110]$. A second mechanism that might be crucial in the reduced bioavailability of $\mathrm{NO}$ in the airways is increased utilisation of L-arginine by arginase, which hydrolyses L-arginine to L-ornithine and urea (fig. 1) [94, 111, 112]. Arginase I and II are both expressed constitutively in the airways, particularly in epithelial cells, (myo)fibroblasts and alveolar macrophages [113-115]. In guinea pigs, it has been discovered that arginase activity is functionally involved in basal airway responsiveness by limiting cNOS-derived NO production [116]. Using airway preparations from the same animal model, it was demonstrated that increased arginase activity may be involved in allergen-induced AHR and reduced iNANC relaxation after the early asthmatic reaction [96, 111]. Moreover, reduced L-arginine availability to iNOS, induced by increased arginase activity as well as reduced transport of the amino acid, may lead to synthesis of both $\mathrm{NO}$ and $\mathrm{O}_{2}{ }^{-}$by this enzyme [117], effectively causing the production of $\mathrm{ONOO}^{-}$, which may contribute to the AHR after the late asthmatic reaction [118, 119].

In various mouse and rat models, it has been confirmed that allergen challenge causes a considerable increase in the expression and activity of particularly arginase type I, most probably via Th2 cytokines involved in the asthmatic airway inflammation [120-127]. Notably, by microarray analysis of gene expression in Balb/c mice sensitised to ovalbumin or Aspergillus fumigatus, it was shown that, among the 291 common genes that were induced by these allergens, enzymes involved in L-arginine metabolism, particularly arginase I and II, belonged to the most predominantly overexpressed genes [127].

Recent studies in asthmatic patients have also indicated increased expression of arginase I in the airways, particularly in epithelial and inflammatory cells [127]. In addition, in asthmatics experiencing an exacerbation, a striking reduction in plasma L-arginine levels has been measured, which was associated with an increase in serum arginase activity [128]. Moreover, increased immunoreactivity against arginase I, which could possibly be induced by nicotine, was recently observed in both the epithelium and the smooth muscle layer of smoking asthmatics [129]. Interestingly, single nucleotide polymorphisms of arginase I and II have recently been found to be associated with atopy and risk of childhood asthma, respectively [130].

Increased metabolism of L-arginine by arginase in the airways may not only compromise NO homeostasis, leading to AHR as a result of reduced bronchodilation and enhanced inflammation, but may also contribute to airway remodelling in chronic disease, through NO-independent pathways mediated by increased production of L-ornithine. Thus L-ornithine is a precursor of the arginase downstream products L-proline and polyamines, which could promote collagen production and growth of mesenchymal cells, such as fibroblasts and smooth muscle cells, respectively [94, 131, 132]. In support of a potential role of arginase in airway fibrosis in asthma, IL-4 and -13 increase arginase I and II expression and arginase activity in cultured rat fibroblasts [114]. In addition, increased levels of polyamines have been observed in mouse lung following allergen challenge [127] and in the serum of asthmatic patients [133], respectively. A role for decreased NO synthesis in airway remodelling can also be envisaged, since NO inhibits proliferation of airway smooth muscle cells [134]. Moreover, reduced NO synthesis could contribute to airway remodelling by increasing the activity of ornithine decarboxylase, which converts L-ornithine to polyamines [135]. The role of arginase in asthmatic airway remodelling remains to be established however.

\section{Cholinergic mechanisms}

The parasympathetic nervous system represents a major bronchoconstrictory pathway. During normal breathing, preganglionic nerves innervating the parasympathetic ganglia in the airways evoke action potentials with relatively high frequencies, in the range $10-20 \mathrm{~Hz}$ [136]. As a result, basal airway smooth muscle tone in vivo is mediated to a significant extent by both ganglionic and post-ganglionic cholinergic nerve activity, of which acetylcholine is the major neurotransmitter. The fidelity with which pre-ganglionic impulses are translated into post-ganglionic action potentials is relatively low, implying a filtering function of these ganglia. Various acute inflammatory mediators, including histamine, prostaglandin (PG) $\mathrm{D}_{2}$ and bradykinin, are able to reduce this filtering function, and, consequently, to enhance ganglionic cholinergic transmission [137]. The same is true for tachykinins (substance $\mathrm{P}$ and neurokinin $\mathrm{A}$ ) released by nonmyelinated sensory C-fibres in the airways [138]. The release of acetylcholine from parasympathetic nerve endings is regulated by a variety of prejunctional receptors that may inhibit or facilitate 
a)
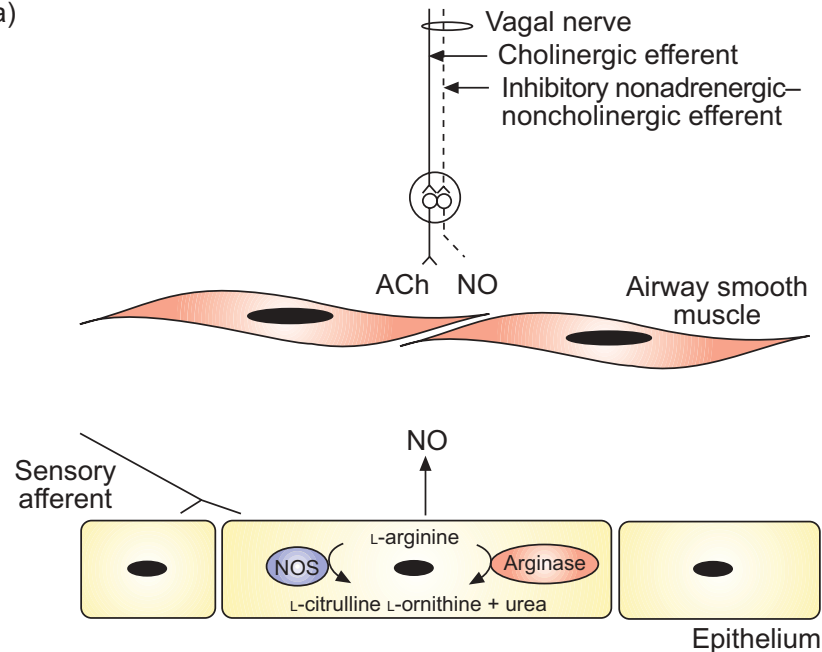

b)

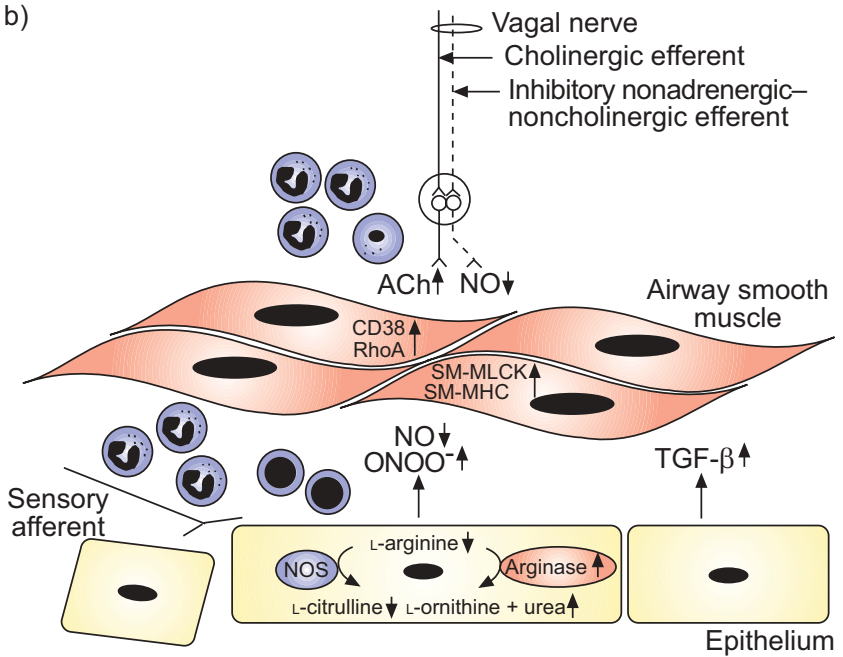

FIGURE 1. Mechanisms of airway hyperresponsiveness: a) healthy airway; and b) asthmatic airway. Airway hyperresponsiveness in asthma has a variable component, caused by acute inflammatory events, and a chronic component, caused by chronic inflammation resulting in structural and phenotypic changes to the airway smooth muscle. In the asthmatic airway, acute hyperresponsiveness is caused, in part, by the enhanced presence of mediators released from inflammatory cells (e.g. histamine and leukotrienes) that directly induce bronchoconstriction and enhance bronchoconstrictor responses to other agonists. In addition, these inflammatory mediators enhance acetylcholine (ACh) release by activating afferent sensory nerve fibres and directly facilitating ganglionic neurotransmission and ACh release from the vagal nerve terminal. ACh release is also augmented by dysfunction of prejunctional muscarinic $\mathrm{M}_{2}$ autoreceptors, caused by the release of the eosinophil product major basic protein (MBP), which acts as an $\mathrm{M}_{2}$ recepter antagonist. Moreover, MBP may cause epithelial damage and increased exposure of afferent sensory nerve fibres. Conversely, the release of bronchodilating nitric oxide (NO) is reduced during airway inflammation as a result of reduced L-arginine availability in the airway epithelium and inhibitory nonadrenergicnoncholinergic nerve endings. Moreover, a low L-arginine concentration promotes the formation of procontractile and pro-inflammatory peroxynitrite (ONOO-), by promoting simultaneous production of $\mathrm{NO}$ and superoxide anion by inducible NO synthase (NOS). The reduction in L-arginine availability is the result of increased expression of the Larginine-consuming enzyme arginase in response to T-helper cell type 2 cytokines (interleukin-4 and -13), as well as inhibition of cationic amino acid transporters by MBP. The enhanced presence of cytokines, growth factors, mediators and contractile neurotransmitters, as well as the reduced presence of NO, also promotes chronic structural and phenotypic changes to the airway smooth muscle layer that superimpose on the variable response to further enhance airway hyperresponsiveness. These structural and phenotypic changes include the enhanced expression of contractile proteins and contraction-regulatory proteins (e.g. smooth muscle (SM) myosin heavy chain (SM-MHC), SM myosin light chain kinase (SM-MLCK), CD38 and RhoA, as well as airway smooth muscle thickening caused by airway smooth muscle hyperplasia and hypertrophy. Collectively, these variable and chronic changes to the airway wall promote airway hyperresponsiveness. TGF- $\beta$ : transforming growth factor- $\beta$. $\uparrow:$ increase; $\downarrow:$ decrease

neurotransmitter outflow. Autoinhibitory muscarinic $\mathrm{M}_{2}$ receptors, activated by acetylcholine itself, represent an important negative feedback, limiting further release, particularly at higher frequencies [139]. In animal models of allergic and viral airway inflammation and asthma, dysfunction of these $\mathrm{M}_{2}$ autoreceptors has been found to contribute to exaggerated acetylcholine release from vagal nerve endings, increased cholinergic reflex activity in response to inhaled stimuli and AHR [140-142]. In allergic guinea pigs, the magnitude of the early asthmatic reaction has been reported to correlate significantly with the extent of $\mathrm{M}_{2}$ autoreceptor dysfunction [142]. $\mathrm{M}_{2}$ autoreceptors have also been found to be dysfunctional in some but not all asthmatics [143-145]. In addition, asthmatics with active viral infections show greater bronchodilatory responses to inhaled anticholinergics, suggesting increased vagal tone [146]. Most of the $\mathrm{M}_{2}$ autoreceptor dysfunction is caused by activated eosinophils that migrate to cholinergic nerves and release MBP, which acts as an allosteric $\mathrm{M}_{2}$ antagonist [147-149]. Taking into consideration the fact that prejunctional $\mathrm{M}_{2}$ receptor function is more prominent in the larger airways [150], it is no surprise that $\mathrm{M}_{2}$ autoreceptor dysfunction is more prominent in asthma than in chronic obstructive pulmonary disease (COPD). Indeed, in patients with stable COPD, $\mathrm{M}_{2}$ autoreceptors appear to function normally [151], although this does not exclude dysfunction during acute exacerbations. Viral infections, which may play a role in exacerbations of both asthma and COPD, induce dysfunction through neuraminidases that cleave portions of the $\mathrm{M}_{2}$ receptor, and through as yet incompletely characterised mechanisms involving macrophages, CD8+ lymphocytes and possibly interferon- $\gamma[152]$

In addition to $\mathrm{M}_{2}$ autoreceptors, a variety of heteroreceptors modulating acetylcholine release have been identified in cholinergic nerve terminals. Catecholamines may inhibit or facilitate acetylcholine overflow through prejunctional $\alpha_{2}$ - and $\beta_{2}$-adrenoceptors, respectively [153-155]. Neurokinins such as substance $\mathrm{P}$ may enhance cholinergic transmission through facilitatory neurokinin-1 and/or -2 receptors [156, 157]. Interestingly, substance $\mathrm{P}$ may also induce MBP release from eosinophils, causing $\mathrm{M}_{2}$ autoreceptor dysfunction, which could act synergistically to direct facilitation [158]. Allergicinflammation-derived prostanoids, including $\mathrm{PGD}_{2}, \mathrm{PGF}_{2 \alpha}$ and thromboxane $\mathrm{A}_{2}$, as well as histamine, can also augment acetylcholine release through prejunctional receptors [138]. Taken together, the above observations indicate that parasympathetic acetylcholine release is governed by various regulatory systems, the set point of which is subject to environmental modulation. During periods of airway inflammation, these modulations often result in enhanced cholinergic 
transmission (fig. 1). Thus AHR following the early asthmatic reaction is reversed by anticholinergics [141], and the bronchoconstrictor response of inhaled inflammatory mediators (e.g. histamine and thromboxane $\mathrm{A}_{2}$ ) is, to a large extent, mediated by cholinergic pathways [141, 159].

Acetylcholine released by post-ganglionic parasympathetic nerves may choose to interact with any one of five muscarinic receptor subtypes, $\mathrm{M}_{1}-\mathrm{M}_{5}$. Most organs and tissues express more than one subtype, and this is also true for many individual cells. In mammalian airways, including those of humans, $\mathrm{M}_{1}, \mathrm{M}_{2}$ and $\mathrm{M}_{3}$ receptors are the most important. $\mathrm{M}_{1}$ receptors are present in type II alveolar cells, presumably mediating/contributing to surfactant production [160, 161], as well as in parasympathetic airway ganglia, where they facilitate ganglionic transmission [138]. Thus vagal bronchoconstriction, induced by sulphur dioxide inhalation, has been found to be especially sensitive to inhaled pirenzepine, an $\mathrm{M}_{1}$ selective antagonist [162]. $\mathrm{M}_{2}$ and $\mathrm{M}_{3}$ receptors represent the major populations, however, in both intra- and extrapulmonary airways. Postjunctional receptor populations in airway smooth muscle are a mixture of $M_{2}$ and $M_{3}$ receptors, the $G_{i^{-}}$ protein $\left(G_{i}\right)$-coupled $M_{2}$ subtype being predominant, particularly in the larger airways. Contraction, however, is primarily mediated by $\mathrm{G}_{\mathrm{q}}$-protein $\left(\mathrm{G}_{\mathrm{q}}\right)$-coupled $\mathrm{M}_{3}$ receptors, even in those smooth muscle preparations in which the ratio of $\mathrm{M}_{2}: \mathrm{M}_{3}$ is 90:10, the $M_{2}$ receptor population playing, at most, a minor supporting role [161]. This was confirmed in airway smooth muscle preparations from $\mathrm{M}_{2}$ receptor knockout mice, in which carbachol was barely less potent than in preparations from wild-type mice [163].

The principal signalling of $\mathrm{G}_{\mathrm{q}}$-coupled receptors is activation of phospholipase $\mathrm{C}$, mediating hydrolysis of phosphatidylinositol 4,5-bisphosphate into inositol 1,4,5-triphosphate $\left(\mathrm{IP}_{3}\right)$ and 1,2-diacylglycerol (DAG). $\mathrm{IP}_{3}$ mobilises $\mathrm{Ca}^{2+}$ ions from intracellular stores, generating a rapid and transient rise in cytosolic free $\mathrm{Ca}^{2+}$ concentration. DAG triggers the translocation and activation of protein kinase C, which is able to phosphorylate a variety of protein substrates [164]. Cross-talk between $\mathrm{G}_{\mathrm{i}}$-coupled $\mathrm{M}_{2}$ receptors and $\mathrm{G}_{\mathrm{s}}$-protein $\left(\mathrm{G}_{\mathrm{s}}\right)$-coupled $\beta$-adrenoceptors (having opposing effects on cyclic AMP accumulation) has no major effects on modulation of muscarinic-agonist-induced contraction or $\beta$-agonist-induced relaxation, at least under physiological conditions [165]. In contrast, $\mathrm{G}_{\mathrm{q}}$-coupled $\mathrm{M}_{3}$ receptors may have a major influence on $\beta$-adrenoceptor function, even in noninflamed airways. This is due to DAG-induced activation of protein kinase $C$, which may: 1) phosphorylate the $\beta_{2}$-adrenoceptor, as well as Gs, causing receptor uncoupling and desensitisation [165]; and 2) phosphorylate and activate $\beta$-adrenoceptor kinases, which are members of the G-protein-coupled receptor kinase family, amplifying homologous $\beta$-agonist induced desensitisation $[166,167]$. These processes may explain the well-known attenuation of $\beta$-agonist efficacy during episodes of severe bronchoconstriction, for example during exacerbations.

In contrast to the enhanced release of acetylcholine due to neuronal mechanisms associated with inflammation, as discussed above, no evidence for upregulation of postjunctional $\mathrm{M}_{3}$ and $\mathrm{M}_{2}$ receptors has been found in hyperresponsive airways of patients with asthma and COPD. However, increased expression and enhanced function of signalling molecules involved in muscarinic-agonist-induced smooth muscle contraction (and mucus secretion) have been identified. Thus several pro-inflammatory cytokines, including IL-1 $\beta$ and tumour necrosis factor $\alpha$, increase $G \alpha_{\mathrm{q}}$ and $G \alpha_{\mathrm{i}}$ expression in airway smooth muscle, which could account for the increased $\mathrm{Ca}^{2+}$ responses to muscarinic agonists and contraction [168, 169]. Coupling of the $M_{3}$ receptor to CD38 enhances the production of cyclic ADP ribose and the release of $\mathrm{Ca}^{2+}$ ions through ryanodine-sensitive stores in the sarcoplasmic reticulum [170]. IL-1 $\beta$, tumour necrosis factor- $\alpha$, IL-13 and interferon- $\gamma$ have also been reported to enhance $\mathrm{Ca}^{2+}$ responses to muscarinic agonists through this mechanism, via increasing CD38 expression [171-174]. Conversely, CD38-deficient mice show reduced AHR towards methacholine, both in vivo and ex vivo, following IL-13 challenge [175]. Collectively, these studies indicate that airway inflammation results in increased cholinergic bronchoconstrictor responses of the asthmatic airway, caused by enhanced neuronal release of acetylcholine and enhanced airway smooth muscle expression of signalling molecules central to muscarinic receptor function.

\section{Rho kinase}

Contraction of airway smooth muscle is primarily regulated by $\mathrm{Ca}^{2+}$-dependent mechanisms, initiated by a (rapid) rise in intracellular $\mathrm{Ca}^{2+}$ concentration, followed by the formation of $\mathrm{Ca}^{2+}$ complexes, which, in turn, activate myosin light chain (MLC) kinase, finally resulting in phosphorylation of the 20$\mathrm{kDa}$ regulatory MLC $\left(\mathrm{MLC}_{20}\right)$. However, $\mathrm{Ca}^{2+}$-independent mechanisms, characterised by augmented smooth muscle shortening at a fixed $\mathrm{Ca}^{2+}$ concentration are also important. This phenomenon is referred to as $\mathrm{Ca}^{2+}{ }^{2+}$ sensitisation [176]. Key regulatory factors of the $\mathrm{Ca}^{2+}$ sensitivity of airway smooth muscle are Rho kinase and the small monomeric G-protein RhoA, its main activator. The RhoA/Rho kinase cascade can be stimulated by a variety of receptors, including those coupled to $\mathrm{G}_{12 / 13}, \mathrm{G}_{\mathrm{i}}$ and $\mathrm{G}_{\mathrm{q}}$. Activated Rho kinase phosphorylates, amongst others, MLC phosphatase (MLCP), which causes dephosphorylation of $\mathrm{MLC}_{20}$; as a consequence, MLCP is inactivated, resulting in enhancement of $\mathrm{MLC}_{20}$ phosphorylation and augmented contraction [41]. Based on this property, and on the pronounced activation of the RhoA/Rho kinase pathway by inflammatory mediators, a role for this pathway in AHR in asthma was recently postulated [41].

The extent to which Rho kinase activation contributes to airway smooth muscle contraction is both agonist- and receptor-dependent. In bovine tracheal smooth muscle preparations, full and partial muscarinic agonists, acting through $\mathrm{M}_{3}$ receptors, are differentially dependent upon Rho kinase for their contractile effects [177]. In the lower concentration ranges, all agonists were sensitive to the Rho kinase inhibitor $(+)-(R)$ trans-4-(1-aminoethyl)-N-(4-pyridyl) cyclohexane carboxamide (Y-27632); in contrast, Y-27632 only reduced maximal contractions induced by partial agonists (such as pilocarpine), whereas the maximal contractions induced by the full agonist methacholine were unaffected. Indeed, an inverse relationship between $\mathrm{Ca}^{2+}$ mobilisation, as well as $\mathrm{Ca}^{2+}$ influx, and the Rho kinase dependency of the contraction induced by these agonists was found [177]. Intriguingly, in both human bronchial [178] and guinea pig tracheal [179, 180] smooth 
muscle preparations, it was found that growth factors and insulin, which act through receptor tyrosine kinases, induce moderate contractions that are totally Rho-kinase-dependent.

In animal models of inflammatory airways disease, evidence indicating a primed role for Rho A/Rho kinase in enhancing obstructive airway responses is accumulating. Thus the functional contribution of Rho kinase in acetylcholine-induced rat bronchial smooth muscle contraction is increased after repeated allergen challenge [181], and parallelled by increased translocation of RhoA to the membrane [182]. Furthermore, active allergic sensitisation of guinea pigs without subsequent allergen exposure is already sufficient to increase RhoA expression and enhance its contribution to contraction ex vivo and airway responsiveness in vivo [183]. Remarkably, similar observations were made using passively sensitised guinea pig airway preparations [184], and recent data indicate that the same is true for cigarette-smoke-induced hyperresponsiveness of rat bronchial smooth muscle [185]. In vivo experiments using a guinea pig model of asthma have further indicated that increased Rho kinase activity contributes to the allergeninduced AHR following both the early and late asthmatic reaction, which is effectively reversed by inhalation of Y-27632 [186]. These data indicate that enhanced Rho/Rho kinase signalling is a feature of AHR in animal models of asthma; its role in human subjects remains to be determined however.

\section{AIRWAY SMOOTH MUSCLE REMODELLING AND AHR Structural and phenotypic alterations of airway smooth muscle in asthma}

In addition to its central role in limiting airflow and regulating variable AHR, it is increasingly evident that chronic structural and phenotypic alterations of the airway smooth muscle superimpose upon the variable response to exaggerate airway smooth muscle contraction (fig. 1) [4]. The smooth muscle mass that encircles the airways and regulates the luminal diameter is considerably thicker in asthmatics [187]. Detailed analyses of the airway smooth muscle bundle obtained from asthmatics have indicated that increases in both airway smooth muscle cell number (hyperplasia) and cell size (hypertrophy) contribute to this response, although the extent to which these processes determine the increase in muscle mass may vary among patients [188-190]. Based on differences in smooth muscle structural characteristics, EBINA et al. [189] even proposed different asthma phenotypes, one characterised primarily by smooth muscle hyperplasia in the central bronchi and another by smooth muscle hypertrophy throughout the bronchial tree. The exact contribution of airway smooth muscle thickening to AHR is not yet completely clear. However, mathematical modelling studies indicate that airway smooth muscle thickening is probably of major importance, perhaps even the primary cause of exaggerated airway narrowing, in the remodelled airway [27, 29]. Importantly, these changes in airway structure worsen with duration of disease, which could contribute to a chronic increase in severity of airway narrowing [191].

Airway smooth muscle proliferation and hypertrophy have been extensively studied in cell culture and animal models of asthma. These studies have revealed that numerous growth factors, contractile agonists, cytokines, proteases and matrix proteins contribute to these responses [7, 192]. Moreover, recent studies indicate that asthmatic airway smooth muscle cells are characterised by an intrinsic functional change, facilitating cell proliferation in culture [52]. This intrinsic change is partially explained by changes in extracellular matrix protein deposition by asthmatic airway smooth muscle [9]. Thus, when normal human airway smooth muscle cells are cultured on an extracellular matrix laid down by asthmatic airway smooth muscle cells, the normal cells also show an increased proliferation rate [9]. Abnormal extracellular matrix production, including increases in fibronectin, are also responsible for the enhanced synthetic capacity of airway smooth muscle cells in the production of eotaxin [51]. A recent study indicated that, in addition to this abnormality, asthmatic airway smooth muscle expresses increased numbers of mitochondria and exhibits increased mitochondrial activity [53]. Increased mitochondrial biogenesis by asthmatic airway smooth muscle is accompanied by increased expression of mitochondrial transcription factor A. Interestingly, the increase in mitochondrial activity and biogenesis is coupled to an increased proliferation rate of these cells [53]. Collectively, these intrinsic biochemical differences suggest that an intrinsic functional change in the asthmatic airway smooth muscle makes the muscle more responsive to mitogens [52, 53, 193, 194]. However, the pathogenic cause of this intrinsic functional change remains unknown.

Asthmatic airway smooth muscle may also produce enhanced contractile responses because of changes in its phenotype that are associated with increased expression of contractile proteins and contraction-regulatory proteins. Isolated asthmatic airway smooth muscle cells have been reported to contract more profoundly and more rapidly in vitro [49]. Furthermore, passive sensitisation of human bronchi with atopic serum increases maximal contractility and agonist sensitivity in vitro [195]. Interestingly, this effect is associated with serum $\operatorname{IgE}$ [196], suggesting a relationship between allergic sensitisation and increased contractile responsiveness. In a canine model of allergic sensitisation, similar effects have been revealed following active sensitisation [197, 198]. This increase in contractility is accompanied by increases in MLC kinase expression, in both the canine model [199] and sensitised human airway smooth muscle $[188,200]$.

Studies using animal models of allergic asthma have demonstrated additional changes in gene expression following sensitisation and/or repeated allergen exposure that may explain increases in the contractile properties of the muscle; the importance of these changes remains to be confirmed for human asthmatic subjects however. RhoA expression (as discussed above) is increased in repeatedly allergen-challenged rats and allergen-sensitised guinea pigs, which may contribute to increased agonist-induced $\mathrm{Ca}^{2+}$ sensitisation in the muscle [41, 181, 183]. A similar role has been identified for the protein $\mathrm{CD} 38$, which regulates cyclic ADP ribose production and subsequent activation of ryanodine receptors on intracellular $\mathrm{Ca}^{2+}$ stores $[170,171]$. The reported increase in mitochondrial biogenesis by asthmatic airway smooth muscle may also contribute to this response, since mitochondria play a known role in airway smooth muscle $\mathrm{Ca}^{2+}$ homeostasis [53].

Expression of contractile proteins, including smooth muscle myosin heavy chain (SM-MHC), is also increased after repeated allergen challenge in guinea pigs [73]. SM-MHC 
exists in several isoforms caused by alternative splicing of a single gene. The so-called (+)insert isoform (also called SM-B), characterised by a seven amino acid insert close to the $\mathrm{N}$ terminus, is characterised by increased cross-bridge cycling activity [201]. Interestingly, a recent study indicated that the expression of the (+)insert of SM-MHC is increased in the hyperresponsive Fisher rat strain, suggesting that this mechanism could also contribute to AHR [202]. These cell and animal studies collectively suggest that changes in the expression of myosin and in proteins that regulate the dynamics of agonistinduced myosin phosphorylation may contribute to allergeninduced AHR. The importance of these findings to the human situation has only partially been revealed and future studies are required in this area.

\section{Pathophysiological mechanisms}

The next relevant question concerns which endogenous mediators regulate these responses and whether or not they can be used as pharmacological targets. From in vitro studies, it is well established that a variety of growth factors, G-proteincoupled receptor agonists, cytokines, proteases and matrix proteins can contribute to the aforementioned responses [7]. Relatively few data are available from animal models, however, although recent research indicates that cysteinyl leukotrienes, acetylcholine and transforming growth factor- $\beta$ (TGF- $\beta$ ) act as important endogenous mediators of airway smooth muscle remodelling in vivo, suggesting that targeting these may be of therapeutic value. The focus in this section is, therefore, on these mediators, especially since drugs targeting cysteinyl leukotrienes and acetylcholine are already clinically available.

Cysteinyl leukotrienes probably play an important regulatory role in airway smooth muscle remodelling. In 1993, WANG et al. [203] demonstrated that blockade of the cysteinyl leukotriene receptor 1 was sufficient to significantly reduce the increase in airway smooth muscle mass observed following repeated allergen exposure in Brown Norway rats. Similar observations were subsequently made in a murine model, showing that the increase in airway smooth muscle mass and increases in Penh following allergen exposure were reduced by treatment of the mice with montelukast [204]. The observation that montelukast administration is able to completely reverse remodelling of the airway smooth muscle bundle, with the experimental treatment starting only after repeated allergen challenges were completed, is spectacular [205]. These data indicate that cysteinyl leukotrienes may play a significant role in the onset and the maintenance of allergen-induced airway smooth muscle thickening.

Cysteinyl leukotrienes probably mediate this response via multiple mechanisms. Cell culture studies indicate that cysteinyl leukotrienes augment the proliferative response of peptide growth factors such as epidermal growth factor (EGF) [206]. Whether or not cysteinyl leukotrienes act as airway smooth muscle mitogens per se remains the subject of debate [206, 207]. The mechanisms responsible for this response have been partially elucidated and appear to involve reactive oxygen species generation and p42/p44 mitogen-activated protein kinase activation, key players in the mitogenic response of airway smooth muscle [207]. These direct effects on the muscle are, however, not the only explanation for the observed effects. Cysteinyl leukotrienes regulate airway inflammation in response to allergen challenge and induce growth factor release from airway structural cells. Thus montelukast inhibits airway eosinophilia and cytokine/chemokine expression in response to allergen challenges in a murine model of asthma [204, 205]. In addition, it was recently established that cysteinyl leukotrienes induce the release from airway epithelial cells of TGF- $\beta$ [208], a key growth factor in many of the structural and phenotypic abnormalities of asthmatic airway smooth muscle, as described below. Therefore, it is likely that these indirect responses too are responsible for the reduction in smooth muscle mass by montelukast.

Acetylcholine, the primary parasympathetic neurotransmitter in the airways, is traditionally associated with bronchoconstriction and mucus secretion. Recent findings are changing this traditional view since acetylcholine production in the airways appears not to be restricted to the parasympathetic nervous system; it is also released from non-neuronal sources, such as the bronchial epithelium and several inflammatory cells [164, 209, 210]. Interestingly, acetylcholine (either neuronal or non-neuronal) also appears to regulate remodelling in a guinea pig model of chronic asthma [72, 73]. Tiotropium treatment of these guinea pigs significantly reduced airway smooth muscle thickening, and had similar protective effects on allergen-induced increases in pulmonary SM-MHC expression and tracheal contractility [73]. This indicates that acetylcholine regulates multiple structural and phenotypic changes in airway smooth muscle caused by allergen exposure.

As observed for cysteinyl leukotrienes, muscarinic receptors on airway smooth muscle also appear to regulate the mitogenic response of airway smooth muscle. The mitogenic effects of platelet-derived growth factor and EGF, for instance, are enhanced, although muscarinic receptors do not themselves mediate mitogenic responses [211, 212]. The augmentation is dependent upon $\mathrm{M}_{3}$ receptors, which augment the intracellular signalling of growth factors by cooperatively regulating phosphorylation of p70S6 kinase and glycogen synthase kinase-3, both resulting in increased cell cycle progression $[212,213]$. Preliminary evidence also indicates that muscarinic receptors regulate the expression of SM-MHC by airway smooth muscle [214]. Nonetheless, it is not unlikely that indirect effects of acetylcholine also contribute to this response. As mentioned earlier, (non-neuronal) acetylcholine regulates aspects of airway inflammation, including eosinophilia in response to allergen exposure and neutrophilia in response to diesel particle inhalation $[72,215]$. Indirect inhibition of airway smooth muscle structural and phenotypic alterations by anticholinergics is therefore also a possibility.

TGF- $\beta$, although not a direct target of drugs marketed for asthma treatment at the moment, appears to be among the most relevant growth factors mediating chronic structural and phenotypic changes in airway smooth muscle. Antibodies directed against TGF- $\beta$, administered intraperitoneally to mice during an antigen challenge protocol, significantly reduced the increase in airway smooth muscle mass without inducing drastic alterations in inflammatory cell recruitment or pulmonary cytokine expression [216]. Likewise, in a Brown Norway rat model of asthma, the TGF- $\beta$ receptor 1 kinase 
inhibitor SD-208 reduced allergen-induced AHR, airway smooth muscle cell proliferation in situ and muscle thickness [217]. These studies indicate that TGF- $\beta$ plays a prominent role in allergen-induced airway smooth muscle structural changes, and in the associated AHR.

The prominent role of TGF- $\beta$ is further revealed by in vitro studies indicating that TGF- $\beta$ plays an important role in most of the structural and phenotypic changes that are observed in asthma. TGF- $\beta$ induces airway smooth muscle proliferation, which, interestingly, is partially dependent upon reactive oxygen species generation, as the result of enhanced transcriptional regulation of reduced nicotinamide adenine dinucleotide phosphate (NADPH) oxidase 4 , a catalytic homologue of NADPH oxidase [218]. TGF- $\beta$ also regulates transcription and translation of contractile proteins and induces airway smooth muscle cell hypertrophy, with the involvement of phosphatidylinositol-3'-kinase and downstream signalling [219]. This indicates that drugs targeting TGF- $\beta$-dependent signalling could achieve a reduction in several smooth muscle abnormalities seen in asthma, although this still needs to be assessed in human subjects.

\section{CONCLUSIONS}

In vitro model systems and animal models of allergic asthma have been successfully applied to the investigation of the mechanisms of acute and chronic airway hyperresponsiveness. In particular, the rapidly growing interest in the role of the airway smooth muscle cell, as a multicompetent cell that may be involved in both functional and structural changes in the airways, has produced interesting novel concepts of pathophysiological mechanisms and has disclosed new directions for future drug treatment. The majority of these mechanisms are linked to acute and chronic inflammatory processes in the airway wall, associated with the release of mediators, growth factors and neurotransmitters that may alter airway smooth muscle function by changes in neural and non-neural control, receptor-mediated signalling pathways, and proliferation and maturation of the muscle cells. Most of these concepts are awaiting translation to the asthmatic patient. Moreover, future studies should also be directed towards critical questions addressing the causal role of inflammation, the functional significance of airway remodelling and the role of genetics in airway hyperresponsiveness.

\section{REFERENCES}

1 Bousquet J, Jeffery PK, Busse WW, Johnson M, Vignola AM. Asthma. From bronchoconstriction to airways inflammation and remodeling. Am J Respir Crit Care Med 2000; 161: 1720-1745.

2 Hargreave FE, O'Byrne PM, Ramsdale EH. Mediators, airway responsiveness, and asthma. I Allergy Clin Immunol 1985; 76: 272-276.

3 Postma DS, Kerstjens HA. Characteristics of airway hyperresponsiveness in asthma and chronic obstructive pulmonary disease. Am J Respir Crit Care Med 1998; 158: S187-S192.

4 An SS, Bai TR, Bates JH, et al. Airway smooth muscle dynamics: a common pathway of airway obstruction in asthma. Eur Respir J 2007; 29: 834-860.
5 Halayko AJ, Solway J. Molecular mechanisms of phenotypic plasticity in smooth muscle cells. J Appl Physiol 2001; 90: 358-368.

6 Halayko AJ, Tran T, Ji SY, Yamasaki A, Gosens R. Airway smooth muscle phenotype and function: interactions with current asthma therapies. Curr Drug Targets 2006; 7: 525-540.

7 Hirst SJ, Martin JG, Bonacci JV, et al. Proliferative aspects of airway smooth muscle. J Allergy Clin Immunol 2004; 114: S2-S17.

8 Howarth PH, Knox AJ, Amrani Y, Tliba O, Panettieri RA Jr, Johnson M. Synthetic responses in airway smooth muscle. J Allergy Clin Immunol 2004; 114: S32-S50.

9 Johnson PR. Role of human airway smooth muscle in altered extracellular matrix production in asthma. Clin Exp Pharmacol Physiol 2001; 28: 233-236.

10 McKay S, Sharma HS. Autocrine regulation of asthmatic airway inflammation: role of airway smooth muscle. Respir Res 2002; 3: 11.

11 Panettieri RA Jr. Airway smooth muscle: an immunomodulatory cell. J Allergy Clin Immunol 2002; 110: S269S274.

12 Cockcroft DW, Davis BE. Mechanisms of airway hyperresponsiveness. J Allergy Clin Immunol 2006; 118: 551-559.

13 Cockcroft DW, Ruffin RE, Dolovich J, Hargreave FE. Allergen-induced increase in non-allergic bronchial reactivity. Clin Allergy 1977; 7: 503-513.

14 Sterk PJ. Virus-induced airway hyperresponsiveness in man. Eur Respir J 1993; 6: 894-902.

15 de Monchy JG, Kauffman HF, Venge $\mathrm{P}$, et al. Bronchoalveolar eosinophilia during allergen-induced late asthmatic reactions. Am Rev Respir Dis 1985; 131: 373-376.

16 Hargreave FE. Late-phase asthmatic responses and airway inflammation. J Allergy Clin Immunol 1989; 83: 525-527.

17 Jeffery PK. Remodeling in asthma and chronic obstructive lung disease. Am J Respir Crit Care Med 2001; 164: S28-S38.

18 Lloyd CM, Robinson DS. Allergen-induced airway remodelling. Eur Respir J 2007; 29: 1020-1032.

19 Postma DS, Timens W. Remodeling in asthma and chronic obstructive pulmonary disease. Proc Am Thorac Soc 2006; 3: 434-439.

20 Barbato A, Turato G, Baraldo S, et al. Epithelial damage and angiogenesis in the airways of children with asthma. Am J Respir Crit Care Med 2006; 174: 975-981.

21 Martinez FD. Asthma treatment and asthma prevention: a tale of 2 parallel pathways. J Allergy Clin Immunol 2007; 119: 30-33.

22 Payne DN, Rogers AV, Adelroth E, et al. Early thickening of the reticular basement membrane in children with difficult asthma. Am J Respir Crit Care Med 2003; 167: 78-82.

23 Saglani S, Bush A. The early-life origins of asthma. Curr Opin Allergy Clin Immunol 2007; 7: 83-90.

24 Holgate ST. Epithelium dysfunction in asthma. J Allergy Clin Immunol 2007; 120: 1233-1244.

25 Mauad T, Bel EH, Sterk PJ. Asthma therapy and airway remodeling. J Allergy Clin Immunol 2007; 120: 997-1009. 
26 Boulet LP, Laviolette M, Turcotte H, et al. Bronchial subepithelial fibrosis correlates with airway responsiveness to methacholine. Chest 1997; 112: 45-52.

27 Lambert RK, Wiggs BR, Kuwano K, Hogg JC, Pare PD. Functional significance of increased airway smooth muscle in asthma and COPD. I Appl Physiol 1993; 74: 2771-2781.

28 McParland BE, Macklem PT, Pare PD. Airway wall remodeling: friend or foe? J Appl Physiol 2003; 95: 426-434.

29 Oliver MN, Fabry B, Marinkovic A, Mijailovich SM, Butler JP, Fredberg JJ. Airway hyperresponsiveness, remodeling, and smooth muscle mass: right answer, wrong reason? Am J Respir Cell Mol Biol 2007; 37: 264-272.

30 Brackel HJ, Pedersen OF, Mulder PG, Overbeek SE, Kerrebijn KF, Bogaard JM. Central airways behave more stiffly during forced expiration in patients with asthma. Am J Respir Crit Care Med 2000; 162: 896-904.

31 Niimi A, Matsumoto H, Takemura M, Ueda T, Chin K, Mishima M. Relationship of airway wall thickness to airway sensitivity and airway reactivity in asthma. Am J Respir Crit Care Med 2003; 168: 983-988.

32 Leckie MJ, ten Brinke A, Khan J, et al. Effects of an interleukin-5 blocking monoclonal antibody on eosinophils, airway hyper-responsiveness, and the late asthmatic response. Lancet 2000; 356: 2144-2148.

33 O'Byrne PM, Inman MD, Parameswaran K. The trials and tribulations of IL-5, eosinophils, and allergic asthma. J Allergy Clin Immunol 2001; 108: 503-508.

34 Lambert RK, Pare PD. Lung parenchymal shear modulus, airway wall remodeling, and bronchial hyperresponsiveness. J Appl Physiol 1997; 83: 140-147.

35 Moreno RH, Hogg JC, Pare PD. Mechanics of airway narrowing. Am Rev Respir Dis 1986; 133: 1171-1180.

36 Cartier A, Thomson NC, Frith PA, Roberts R, Hargreave FE. Allergen-induced increase in bronchial responsiveness to histamine: relationship to the late asthmatic response and change in airway caliber. J Allergy Clin Immunol 1982; 70: 170-177.

37 Ihre E, Zetterstrom O. Increase in non-specific bronchial responsiveness after repeated inhalation of low doses of allergen. Clin Exp Allergy 1993; 23: 298-305.

38 Ihre E, Gyllfors P, Gustafsson LE, Kumlin M, Dahlen B. Early rise in exhaled nitric oxide and mast cell activation in repeated low-dose allergen challenge. Eur Respir J 2006; 27: 1152-1159.

39 Amrani Y, Tliba O, Deshpande DA, Walseth TF, Kannan MS, Panettieri RA Jr. Bronchial hyperresponsiveness: insights into new signaling molecules. Curr Opin Pharmacol 2004; 4: 230-234.

40 Barnes PJ. Pharmacology of airway smooth muscle. Am J Respir Crit Care Med 1998; 158: S123-S132.

41 Gosens R, Schaafsma D, Nelemans SA, Halayko AJ. Rhokinase as a drug target for the treatment of airway hyperresponsiveness in asthma. Mini Rev Med Chem 2006; 6: 339-348.

42 Meurs H, Zaagsma J. Pharmacological and biochemical changes in airway smooth muscle in relation to bronchial hyperresponsiveness. In: Agrawal DK, Townley RG, eds. Inflammatory Cells and Mediators in Bronchial Asthma. Boca Raton, CRC Press, Inc., 1991; pp. 1-38.
43 Zaagsma J, Roffel AF, Meurs H. Muscarinic control of airway function. Life Sci 1997; 60: 1061-1068.

44 Hall IP, Kotlikoff M. Use of cultured airway myocytes for study of airway smooth muscle. Am J Physiol 1995; 268: L1-L11.

45 Hall IP. Second messengers, ion channels and pharmacology of airway smooth muscle. Eur Respir J 2000; 15: 1120-1127.

46 Hirst SJ. Airway smooth muscle cell culture: application to studies of airway wall remodelling and phenotype plasticity in asthma. Eur Respir J 1996; 9: 808-820.

47 Hirst SJ. Airway smooth muscle as a target in asthma. Clin Exp Allergy 2000; 30: Suppl. 1, 54-59.

48 Penn RB, Benovic JL. Regulation of heterotrimeric G protein signaling in airway smooth muscle. Proc Am Thorac Soc 2008; 5: 47-57.

49 Ma X, Cheng Z, Kong H, et al. Changes in biophysical and biochemical properties of single bronchial smooth muscle cells from asthmatic subjects. Am J Physiol Lung Cell Mol Physiol 2002; 283: L1181-L1189.

50 Oliver BG, Black JL. Airway smooth muscle and asthma. Allergol Int 2006; 55: 215-223.

51 Chan V, Burgess JK, Ratoff JC, et al. Extracellular matrix regulates enhanced eotaxin expression in asthmatic airway smooth muscle cells. Am J Respir Crit Care Med 2006; 174: 379-385.

52 Johnson PR, Roth M, Tamm M, et al. Airway smooth muscle cell proliferation is increased in asthma. Am J Respir Crit Care Med 2001; 164: 474-477.

53 Trian T, Benard G, Begueret H, et al. Bronchial smooth muscle remodeling involves calcium-dependent enhanced mitochondrial biogenesis in asthma. J Exp Med 2007; 3173-3181.

54 Canning BJ. Modeling asthma and COPD in animals: a pointless exercise? Curr Opin Pharmacol 2003; 3: 244-250.

55 Kumar RK, Foster PS. Modeling allergic asthma in mice: pitfalls and opportunities. Am J Respir Cell Mol Biol 2002; 27: 267-272.

56 Martin JG, Tamaoka M. Rat models of asthma and chronic obstructive lung disease. Pulm Pharmacol Ther 2006; 19: 377-385.

57 Meurs H, Santing RE, Remie R, et al. A guinea pig model of acute and chronic asthma using permanently instrumented and unrestrained animals. Nat Protoc 2006; 1: 840-847.

58 Zosky GR, Sly PD. Animal models of asthma. Clin Exp Allergy 2007; 37: 973-988.

59 Johnson JR, Wiley RE, Fattouh R, et al. Continuous exposure to house dust mite elicits chronic airway inflammation and structural remodeling. Am J Respir Crit Care Med 2004; 169: 378-385.

60 Kariyawasam HH, Robinson DS. Airway remodelling in asthma: models and supermodels? Clin Exp Allergy 2005; 35: 117-121.

61 Leigh R, Ellis R, Wattie J, et al. Dysfunction and remodeling of the mouse airway persist after resolution of acute allergen-induced airway inflammation. Am J Respir Cell Mol Biol 2002; 27: 526-535.

62 McMillan SJ, Lloyd CM. Prolonged allergen challenge in mice leads to persistent airway remodelling. Clin Exp Allergy 2004; 34: 497-507. 
63 Zosky GR, Larcombe AN, White OJ, et al. Ovalbuminsensitized mice are good models for airway hyperresponsiveness but not acute physiological responses to allergen inhalation. Clin Exp Allergy 2008; 38: 829-838.

64 Irvin CG, Bates JH. Measuring the lung function in the mouse: the challenge of size. Respir Res 2003; 4: 4.

65 Hamelmann E, Schwarze J, Takeda K, et al. Noninvasive measurement of airway responsiveness in allergic mice using barometric plethysmography. Am J Respir Crit Care Med 1997; 156: 766-775.

66 Bates J, Irvin C, Brusasco V, et al. The use and misuse of Penh in animal models of lung disease. Am J Respir Cell Mol Biol 2004; 31: 373-374.

67 Sly PD, Turner DJ, Collins RA, Hantos Z. Penh is not a validated technique for measuring airway function in mice. Am J Respir Crit Care Med 2005; 172: 256.

68 Matsumoto T, Ashida Y, Tsukuda R. Pharmacological modulation of immediate and late airway response and leukocyte infiltration in the guinea pig. J Pharmacol Exp Ther 1994; 269: 1236-1244.

69 Ressmeyer AR, Larsson AK, Vollmer E, Dahlen SE, Uhlig S, Martin C. Characterisation of guinea pig precision-cut lung slices: comparison with human tissues. Eur Respir J 2006; 28: 603-611.

70 Santing RE, Olymulder CG, Zaagsma J, Meurs H. Relationships among allergen-induced early and late phase airway obstructions, bronchial hyperreactivity, and inflammation in conscious, unrestrained guinea pigs. J Allergy Clin Immunol 1994; 93: 1021-1030.

71 Toward TJ, Broadley KJ. Early and late bronchoconstrictions, airway hyper-reactivity, leucocyte influx and lung histamine and nitric oxide after inhaled antigen: effects of dexamethasone and rolipram. Clin Exp Allergy 2004; 34: 91-102.

72 Bos IS, Gosens R, Zuidhof AB, et al. Inhibition of allergeninduced airway remodelling by tiotropium and budesonide: a comparison. Eur Respir J 2007; 30: 653-661.

73 Gosens R, Bos IS, Zaagsma J, Meurs H. Protective effects of tiotropium bromide in the progression of airway smooth muscle remodeling. Am J Respir Crit Care Med 2005; 171: 1096-1102.

74 Prado CM, Leick-Maldonado EA, Yano L, et al. Effects of nitric oxide synthases in chronic allergic airway inflammation and remodeling. Am J Respir Cell Mol Biol 2006; 35: 457-465.

75 Moncada S, Palmer RM, Higgs EA. Biosynthesis of nitric oxide from L-arginine. A pathway for the regulation of cell function and communication. Biochem Pharmacol 1989; 38: 1709-1715.

76 Ricciardolo FL, Sterk PJ, Gaston B, Folkerts G. Nitric oxide in health and disease of the respiratory system. Physiol Rev 2004; 84: 731-765.

77 de Boer J, Meurs H, Coers W, et al. Deficiency of nitric oxide in allergen-induced airway hyperreactivity to contractile agonists after the early asthmatic reaction: an ex vivo study. Br J Pharmacol 1996; 119: 1109-1116.

78 Nijkamp FP, van der Linde HJ, Folkerts G. Nitric oxide synthesis inhibitors induce airway hyperresponsiveness in the guinea pig in vivo and in vitro. Role of the epithelium. Am Rev Respir Dis 1993; 148: 727-734.
79 Cirino G, Fiorucci S, Sessa WC. Endothelial nitric oxide synthase: the Cinderella of inflammation? Trends Pharmacol Sci 2003; 24: 91-95.

80 Cook S, Vollenweider P, Menard B, Egli M, Nicod P, Scherrer U. Increased eNO and pulmonary iNOS expression in eNOS null mice. Eur Respir J 2003; 21 : 770-773.

81 Ten Broeke R, De Crom R, Van Haperen R, et al. Overexpression of endothelial nitric oxide synthase suppresses features of allergic asthma in mice. Respir Res 2006; 7: 58.

82 Thomassen MJ, Buhrow LT, Connors MJ, Kaneko FT, Erzurum SC, Kavuru MS. Nitric oxide inhibits inflammatory cytokine production by human alveolar macrophages. Am J Respir Cell Mol Biol 1997; 17: 279-283.

83 Asano K, Chee CB, Gaston B, et al. Constitutive and inducible nitric oxide synthase gene expression, regulation, and activity in human lung epithelial cells. Proc Natl Acad Sci USA 1994; 91: 10089-10093.

84 Hamid Q, Springall DR, Riveros-Moreno V, et al. Induction of nitric oxide synthase in asthma. Lancet 1993; 342: 1510-1513.

85 Kharitonov SA, Yates D, Robbins RA, Logan-Sinclair R, Shinebourne EA, Barnes PJ. Increased nitric oxide in exhaled air of asthmatic patients. Lancet 1994; 343: 133-135.

86 Kharitonov SA, O'Connor BJ, Evans DJ, Barnes PJ. Allergen-induced late asthmatic reactions are associated with elevation of exhaled nitric oxide. Am J Respir Crit Care Med 1995; 151: 1894-1899.

87 Yan ZQ, Hansson GK, Skoogh BE, Lötvall JO. Induction of nitric oxide synthase in a model of allergic occupational asthma. Allergy 1995; 50: 760-764.

88 Sadeghi-Hashjin G, Folkerts G, Henricks PA, Muijsers RB, Nijkamp FP. Peroxynitrite in airway diseases. Clin Exp Allergy 1998; 28: 1464-1473.

89 Saleh D, Ernst P, Lim S, Barnes PJ, Giaid A. Increased formation of the potent oxidant peroxynitrite in the airways of asthmatic patients is associated with induction of nitric oxide synthase: effect of inhaled glucocorticoid. FASEB J 1998; 12: 929-937.

90 Dupont LJ, Rochette F, Demedts MG, Verleden GM. Exhaled nitric oxide correlates with airway hyperresponsiveness in steroid-naive patients with mild asthma. Am J Respir Crit Care Med 1998; 157: 894-898.

91 Jatakanon A, Lim S, Kharitonov SA, Chung KF, Barnes PJ. Correlation between exhaled nitric oxide, sputum eosinophils, and methacholine responsiveness in patients with mild asthma. Thorax 1998; 53: 91-95.

92 Jatakanon A, Lim S, Chung KF, Barnes PJ. An inhaled steroid improves markers of airway inflammation in patients with mild asthma. Eur Respir J 1998; 12: 10841088.

93 Kharitonov SA, Barnes PJ. Clinical aspects of exhaled nitric oxide. Eur Respir J 2000; 16: 781-792.

94 Meurs H, Maarsingh H, Zaagsma J. Arginase and asthma: novel insights into nitric oxide homeostasis and airway hyperresponsiveness. Trends Pharmacol Sci 2003; 24: $450-455$.

95 Persson MG, Gustafsson LE. Allergen-induced airway obstruction in guinea-pigs is associated with changes in 
nitric oxide levels in exhaled air. Acta Physiol Scand 1993; 149: 461-466.

96 Maarsingh H, Leusink J, Bos IS, Zaagsma J, Meurs H. Arginase strongly impairs neuronal nitric oxidemediated airway smooth muscle relaxation in allergic asthma. Respir Res 2006; 7: 6.

97 Schuiling $M$, Meurs $H$, Zuidhof AB, Venema N, Zaagsma J. Dual action of iNOS-derived nitric oxide in allergen-induced airway hyperreactivity in conscious, unrestrained guinea pigs. Am J Respir Crit Care Med 1998; 158: 1442-1449.

98 Mehta S, Drazen JM, Lilly CM. Endogenous nitric oxide and allergic bronchial hyperresponsiveness in guinea pigs. Am J Physiol 1997; 273: L656-L662.

99 Miura M, Yamauchi H, Ichinose M, et al. Impairment of neural nitric oxide-mediated relaxation after antigen exposure in guinea pig airways in vitro. Am J Respir Crit Care Med 1997; 156: 217-222.

100 Ricciardolo FL, Di Maria GU, Mistretta A, Sapienza MA, Geppetti P. Impairment of bronchoprotection by nitric oxide in severe asthma. Lancet 1997; 350: 1297-1298.

101 Ricciardolo FL, Timmers MC, Geppetti P, et al. Allergeninduced impairment of bronchoprotective nitric oxide synthesis in asthma. J Allergy Clin Immunol 2001; 108: 198-204.

102 Brown RH, Mitzner W. Airway response to deep inspiration: role of nitric oxide. Eur Respir J 2003; 22: 57-61.

103 Scichilone N, Pyrgos G, Kapsali T, et al. Airways hyperresponsiveness and the effects of lung inflation. Int Arch Allergy Immunol 2001; 124: 262-266.

104 Skloot G, Permutt S, Togias A. Airway hyperresponsiveness in asthma: a problem of limited smooth muscle relaxation with inspiration. J Clin Invest 1995; 96: 23932403.

105 Slats AM, Janssen K, van Schadewijk A, et al. Bronchial inflammation and airway responses to deep inspiration in asthma and chronic obstructive pulmonary disease. Am J Respir Crit Care Med 2007; 176: 121-128.

106 Samb A, Pretolani M, Dinh-Xuan AT, et al. Decreased pulmonary and tracheal smooth muscle expression and activity of type 1 nitric oxide synthase (nNOS) after ovalbumin immunization and multiple aerosol challenge in guinea pigs. Am J Respir Crit Care Med 2001; 164: 149-154.

107 de Boer J, Duyvendak M, Schuurman FE, Pouw FM, Zaagsma J, Meurs H. Role of L-arginine in the deficiency of nitric oxide and airway hyperreactivity after the allergen-induced early asthmatic reaction in guinea-pigs. Br J Pharmacol 1999; 128: 1114-1120.

108 Hammermann R, Hirschmann J, Hey C, et al. Cationic proteins inhibit L-arginine uptake in rat alveolar macrophages and tracheal epithelial cells. Implications for nitric oxide synthesis. Am J Respir Cell Mol Biol 1999; 21: 155-162.

109 Maarsingh H, de Boer J, Kauffman HF, Zaagsma J, Meurs H. Heparin normalizes allergen-induced nitric oxide deficiency and airway hyperresponsiveness. $\mathrm{Br} \mathrm{J}$ Pharmacol 2004; 142: 1293-1299.

110 Meurs H, Schuurman FE, Duyvendak M, Zaagsma J. Deficiency of nitric oxide in polycation-induced airway hyperreactivity. Br J Pharmacol 1999; 126: 559-562.
111 Meurs H, McKay S, Maarsingh $\mathrm{H}$, et al. Increased arginase activity underlies allergen-induced deficiency of cNOS-derived nitric oxide and airway hyperresponsiveness. Br J Pharmacol 2002; 136: 391-398.

112 Ricciardolo FL, Zaagsma J, Meurs H. The therapeutic potential of drugs targeting the arginase pathway in asthma. Expert Opin Investig Drugs 2005; 14: 1221-1231.

113 Klasen S, Hammermann R, Fuhrmann M, et al. Glucocorticoids inhibit lipopolysaccharide-induced upregulation of arginase in rat alveolar macrophages. $\mathrm{Br} J$ Pharmacol 2001; 132: 1349-1357.

114 Lindemann D, Racke K. Glucocorticoid inhibition of interleukin-4 (IL-4) and interleukin-13 (IL-13) induced up-regulation of arginase in rat airway fibroblasts. Naunyn Schmiedebergs Arch Pharmacol 2003; 368: 546-550.

115 Que LG, Kantrow SP, Jenkinson CP, Piantadosi CA, Huang YC. Induction of arginase isoforms in the lung during hyperoxia. Am J Physiol 1998; 275: L96-L102.

116 Meurs H, Hamer MA, Pethe S, Vadon-Le Goff S, Boucher JL, Zaagsma J. Modulation of cholinergic airway reactivity and nitric oxide production by endogenous arginase activity. Br J Pharmacol 2000; 130: 1793-1798.

117 Xia Y, Zweier JL. Superoxide and peroxynitrite generation from inducible nitric oxide synthase in macrophages. Proc Natl Acad Sci USA 1997; 94: 6954-6958.

118 de Boer J, Meurs H, Flendrig L, Koopal M, Zaagsma J. Role of nitric oxide and superoxide in allergen-induced airway hyperreactivity after the late asthmatic reaction in guinea-pigs. Br J Pharmacol 2001; 133: 1235-1242.

119 Maarsingh H, Bossenga BB, Bos IST, Zaagsma J, Meurs H. Arginase- and polycation-induced L-arginine limitation causes deficiency of bronchodilating NO and airway hyperreactivity after the late asthmatic reaction. Eur Respir J 2004; 24: Suppl. 48, 681s.

120 Abe M, Hayashi Y, Murai A, et al. Effects of inducible nitric oxide synthase inhibitors on asthma depending on administration schedule. Free Radic Biol Med 2006; 40: 1083-1095.

121 Fajardo I, Svensson L, Bucht A, Pejler G. Increased levels of hypoxia-sensitive proteins in allergic airway inflammation. Am J Respir Crit Care Med 2004; 170: 477-484.

122 Greene AL, Rutherford MS, Regal RR, et al. Arginase activity differs with allergen in the effector phase of ovalbumin- versus trimellitic anhydride-induced asthma. Toxicol Sci 2005; 88: 420-433.

123 Lewis CC, Yang JY, Huang X, et al. Disease-specific gene expression profiling in multiple models of lung disease. Am J Respir Crit Care Med 2008; 177: 376-387.

124 Sharkhuu T, Matthaei KI, Forbes E, et al. Mechanism of interleukin-25 (IL-17E)-induced pulmonary inflammation and airways hyper-reactivity. Clin Exp Allergy 2006; 36: 1575-1583.

125 Takemoto K, Ogino K, Shibamori M, et al. Transiently, paralleled upregulation of arginase and nitric oxide synthase and the effect of both enzymes on the pathology of asthma. Am J Physiol Lung Cell Mol Physiol 2007; 293: L1419-L1426.

126 Yang M, Rangasamy D, Matthaei KI, et al. Inhibition of arginase I activity by RNA interference attenuates IL-13induced airways hyperresponsiveness. J Immunol 2006; 177: 5595-5603. 
127 Zimmermann N, King NE, Laporte J, et al. Dissection of experimental asthma with DNA microarray analysis identifies arginase in asthma pathogenesis. J Clin Invest 2003; 111: 1863-1874.

128 Morris CR, Poljakovic M, Lavrisha L, Machado L, Kuypers FA, Morris SM Jr. Decreased arginine bioavailability and increased serum arginase activity in asthma. Am J Respir Crit Care Med 2004; 170: 148-153.

129 Bergeron C, Boulet LP, Page N, et al. Influence of cigarette smoke on the arginine pathway in asthmatic airways: increased expression of arginase I. J Allergy Clin Immunol 2007; 119: 391-397.

130 Li H, Romieu I, Sienra-Monge JJ, et al. Genetic polymorphisms in arginase I and II and childhood asthma and atopy. J Allergy Clin Immunol 2006; 117: 119-126.

131 Hoet PH, Nemery B. Polyamines in the lung: polyamine uptake and polyamine-linked pathological or toxicological conditions. Am J Physiol Lung Cell Mol Physiol 2000; 278: L417-L433.

$132 \mathrm{Wu}$ G, Morris SM Jr. Arginine metabolism: nitric oxide and beyond. Biochem J 1998; 336: 1-17.

133 Kurosawa M, Shimizu Y, Tsukagoshi H, Ueki M. Elevated levels of peripheral-blood, naturally occurring aliphatic polyamines in bronchial asthmatic patients with active symptoms. Allergy 1992; 47: 638-643.

134 Hamad AM, Knox AJ. Mechanisms mediating the antiproliferative effects of nitric oxide in cultured human airway smooth muscle cells. FEBS Lett 2001; 506: 91-96.

135 Bauer PM, Buga GM, Fukuto JM, Pegg AE, Ignarro LJ. Nitric oxide inhibits ornithine decarboxylase via $S$ nitrosylation of cysteine 360 in the active site of the enzyme. J Biol Chem 2001; 276: 34458-34464.

136 Mitchell RA, Herbert DA, Baker DG, Basbaum CB. In vivo activity of tracheal parasympathetic ganglion cells innervating tracheal smooth muscle. Brain Res 1987; 437: 157-160.

137 Myers AC. Transmission in autonomic ganglia. Respir Physiol 2001; 125: 99-111.

138 Undem BJ, Myers AC. Cholinergic and noncholinergic parasympathetic control of airway smooth muscle. In: Zaagsma J, Meurs H, Roffel AF, eds. Muscarinic Receptors in Airways Diseases. Basle, Birkhäuser Verlag, 2001; pp. 1-24.

139 ten Berge RE, Weening EC, Roffel AF, Zaagsma J. Differences in the prejunctional effects of methacholine and pilocarpine on the release of endogenous acetylcholine from guinea-pig trachea. Naunyn Schmiedebergs Arch Pharmacol 1996; 354: 606-611.

140 Coulson FR, Fryer AD. Muscarinic acetylcholine receptors and airway diseases. Pharmacol Ther 2003; 98: 59-69.

141 Santing RE, Pasman Y, Olymulder CG, Roffel AF, Meurs H, Zaagsma J. Contribution of a cholinergic reflex mechanism to allergen-induced bronchial hyperreactivity in permanently instrumented, unrestrained guinea-pigs. Br J Pharmacol 1995; 114: 414-418.

142 ten Berge RE, Santing RE, Hamstra JJ, Roffel AF, Zaagsma J. Dysfunction of muscarinic $\mathrm{M}_{2}$ receptors after the early allergic reaction: possible contribution to bronchial hyperresponsiveness in allergic guinea-pigs. Br J Pharmacol 1995; 114: 881-887.
143 Ayala LE, Ahmed T. Is there loss of protective muscarinic receptor mechanism in asthma? Chest 1989; 96: 1285-1291.

144 Minette PA, Lammers JW, Dixon CM, McCusker MT, Barnes PJ. A muscarinic agonist inhibits reflex bronchoconstriction in normal but not in asthmatic subjects. J Appl Physiol 1989; 67: 2461-2465.

145 Okayama M, Shen T, Midorikawa J, et al. Effect of pilocarpine on propranolol-induced bronchoconstriction in asthma. Am J Respir Crit Care Med 1994; 149: 76-80.

146 Kanazawa H, Hirata K, Yoshikawa J. Increased responses to inhaled oxitropium bromide in asthmatic patients with active hepatitis C virus infection. Chest 2004; 125: 13681371.

147 Adamko DJ, Yost BL, Gleich GJ, Fryer AD, Jacoby DB. Ovalbumin sensitization changes the inflammatory response to subsequent parainfluenza infection. Eosinophils mediate airway hyperresponsiveness, $\mathrm{M}_{2}$ muscarinic receptor dysfunction, and antiviral effects. J Exp Med 1999; 190: 1465-1478.

148 Costello RW, Schofield BH, Kephart GM, Gleich GJ, Jacoby DB, Fryer AD. Localization of eosinophils to airway nerves and effect on neuronal $\mathrm{M}_{2}$ muscarinic receptor function. Am J Physiol 1997; 273: L93-L103.

149 Jacoby DB, Gleich GJ, Fryer AD. Human eosinophil major basic protein is an endogenous allosteric antagonist at the inhibitory muscarinic $\mathrm{M}_{2}$ receptor. J Clin Invest 1993; 91: 1314-1318.

150 ten Berge RE, Zaagsma J, Roffel AF. Muscarinic inhibitory autoreceptors in different generations of human airways. Am J Respir Crit Care Med 1996; 154: 43-49.

151 On LS, Boonyongsunchai P, Webb S, Davies L, Calverley PM, Costello RW. Function of pulmonary neuronal $\mathrm{M}_{2}$ muscarinic receptors in stable chronic obstructive pulmonary disease. Am J Respir Crit Care Med 2001; 163: 1320-1325.

152 Belmonte KE. Cholinergic pathways in the lungs and anticholinergic therapy for chronic obstructive pulmonary disease. Proc Am Thorac Soc 2005; 2: 297-304.

153 Baker DG, Don HF, Brown JK. Alpha-adrenergic and muscarinic cholinergic inhibition of $\mathrm{ACh}$ release in guinea pig trachea: role of neuronal $\mathrm{K}^{+}$channels. Am J Physiol 1994; 266: L698-L704.

154 de Haas JR, Terpstra JS, van der Zwaag M, Kockelbergh PG, Roffel AF, Zaagsma J. Facilitatory $\beta_{2^{-}}$ adrenoceptors on cholinergic and adrenergic nerve endings of the guinea pig trachea. Am J Physiol 1999; 276: L420-L425.

155 Zhang XY, Robinson NE, Wang ZW, Lu MC. Catecholamine affects acetylcholine release in trachea: alpha 2-mediated inhibition and beta 2-mediated augmentation. Am J Physiol 1995; 268: L368-L373.

156 Belvisi MG, Patacchini R, Barnes PJ, Maggi CA. Facilitatory effects of selective agonists for tachykinin receptors on cholinergic neurotransmission: evidence for species differences. Br J Pharmacol 1994; 111: 103-110.

157 Hey JA, Danko G, del Prado M, Chapman RW. Augmentation of neurally evoked cholinergic bronchoconstrictor responses by prejunctional $\mathrm{NK}_{2}$ receptors in the guinea-pig. J Auton Pharmacol 1996; 16: 41-48.

158 Evans CM, Belmonte KE, Costello RW, Jacoby DB, Gleich GJ, Fryer AD. Substance P-induced airway 
hyperreactivity is mediated by neuronal $\mathrm{M}_{2}$ receptor dysfunction. Am J Physiol Lung Cell Mol Physiol 2000; 279: L477-L486.

159 Allen IC, Hartney JM, Coffman TM, Penn RB, Wess J, Koller $\mathrm{BH}$. Thromboxane $\mathrm{A}_{2}$ induces airway constriction through an $\mathrm{M}_{3}$ muscarinic acetylcholine receptor-dependent mechanism. Am J Physiol Lung Cell Mol Physiol 2006; 290: L526-L533.

160 Brown LA, Longmore WJ. Adrenergic and cholinergic regulation of lung surfactant secretion in the isolated perfused rat lung and in the alveolar type II cell in culture. J Biol Chem 1981; 256: 66-72.

161 Roffel AF, Meurs H, Zaagsma J. Identification, localization and function of muscarinic receptor subtypes in the airways. In: Zaagsma J, Meurs H, Roffel AF, eds. Muscarinic Receptors in Airways Diseases. Basel, Birkhäuser Verlag, 2001; pp. 63-85.

162 Lammers JW, Minette P, McCusker M, Barnes PJ. The role of pirenzepine-sensitive $\left(\mathrm{M}_{1}\right)$ muscarinic receptors in vagally mediated bronchoconstriction in humans. Am Rev Respir Dis 1989; 139: 446-449.

163 Wess J. Muscarinic acetylcholine receptor knockout mice: novel phenotypes and clinical implications. Annu Rev Pharmacol Toxicol 2004; 44: 423-450.

164 Gosens R, Zaagsma J, Meurs H, Halayko AJ. Muscarinic receptor signaling in the pathophysiology of asthma and COPD. Respir Res 2006; 7: 73.

165 Meurs H, Roffel AF, Elzinga CRS, Zaagsma J. Muscarinic receptor- $\beta$-adrenoceptor cross-talk in airway smooth muscle. In: Zaagsma J, Meurs H, Roffel AF, eds. Muscarinic Receptors in Airways Diseases. Basel, Birkhäuser Verlag, 2001; pp. 121-157.

166 De Blasi A, Parruti G, Sallese M. Regulation of G proteincoupled receptor kinase subtypes in activated T lymphocytes. Selective increase of beta-adrenergic receptor kinase 1 and 2. J Clin Invest 1995; 95: 203-210.

167 Boterman M, Smits SR, Meurs H, Zaagsma J. Protein kinase $\mathrm{C}$ potentiates homologous desensitization of the $\beta_{2}$-adrenoceptor in bovine tracheal smooth muscle. Eur J Pharmacol 2006; 529: 151-156.

168 Hakonarson H, Herrick DJ, Serrano PG, Grunstein MM. Mechanism of cytokine-induced modulation of betaadrenoceptor responsiveness in airway smooth muscle. J Clin Invest 1996; 97: 2593-2600.

169 Hotta K, Emala CW, Hirshman CA. TNF- $\alpha$ upregulates $\mathrm{G}_{\mathrm{i}} \alpha$ and $\mathrm{G}_{\mathrm{q}} \alpha$ protein expression and function in human airway smooth muscle cells. Am J Physiol 1999; 276: L405L411.

170 Deshpande DA, White TA, Dogan S, Walseth TF, Panettieri RA, Kannan MS. CD38/cyclic ADP-ribose signaling: role in the regulation of calcium homeostasis in airway smooth muscle. Am J Physiol Lung Cell Mol Physiol 2005; 288: L773-L788.

171 Deshpande DA, Walseth TF, Panettieri RA, Kannan MS. CD38/cyclic ADP-ribose-mediated $\mathrm{Ca}^{2+}$ signaling contributes to airway smooth muscle hyperresponsiveness. FASEB J 2003; 17: 452-454.

172 Tliba O, Panettieri RA Jr, Tliba S, Walseth TF, Amrani Y. Tumor necrosis factor $\alpha$ differentially regulates the expression of proinflammatory genes in human airway smooth muscle cells by activation of interferon- $\beta$-dependent CD38 pathway. Mol Pharmacol 2004; 66: 322-329.

173 Deshpande DA, Dogan S, Walseth TF, et al. Modulation of calcium signaling by interleukin-13 in human airway smooth muscle: role of CD38/cyclic adenosine diphosphate ribose pathway. Am J Respir Cell Mol Biol 2004; 31: 36-42.

174 Tliba O, Cidlowski JA, Amrani Y. CD38 expression is insensitive to steroid action in cells treated with tumor necrosis factor- $\alpha$ and interferon- $\gamma$ by a mechanism involving the up-regulation of the glucocorticoid receptor $\beta$ isoform. Mol Pharmacol 2006; 69: 588-596.

175 Guedes AG, Paulin J, Rivero-Nava L, Kita H, Lund FE, Kannan MS. CD38-deficient mice have reduced airway hyperresponsiveness following IL-13 challenge. Am J Physiol Lung Cell Mol Physiol 2006; 291: L1286-L1293.

176 de Lanerolle P, Paul RJ. Myosin phosphorylation/dephosphorylation and regulation of airway smooth muscle contractility. Am J Physiol 1991; 261: L1-L14.

177 Schaafsma D, Boterman M, de Jong AM, et al. Differential Rho-kinase dependency of full and partial muscarinic receptor agonists in airway smooth muscle contraction. Br J Pharmacol 2006; 147: 737-743.

178 Gosens R, Schaafsma D, Grootte Bromhaar MM, et al. Growth factor-induced contraction of human bronchial smooth muscle is Rho-kinase-dependent. Eur J Pharmacol 2004; 494: 73-76.

179 Schaafsma D, Gosens R, Bos IS, Meurs H, Zaagsma J, Nelemans SA. Role of contractile prostaglandins and Rho-kinase in growth factor-induced airway smooth muscle contraction. Respir Res 2005; 6: 85.

180 Schaafsma D, Gosens R, Ris JM, Zaagsma J, Meurs H, Nelemans SA. Insulin induces airway smooth muscle contraction. Br J Pharmacol 2007; 150: 136-142.

181 Chiba Y, Takada Y, Miyamoto S, MitsuiSaito M, Karaki H, Misawa M. Augmented acetylcholine-induced, Rhomediated $\mathrm{Ca}^{2+}$ sensitization of bronchial smooth muscle contraction in antigen-induced airway hyperresponsive rats. Br J Pharmacol 1999; 127: 597-600.

182 Chiba Y, Sakai H, Misawa M. Augmented acetylcholineinduced translocation of RhoA in bronchial smooth muscle from antigen-induced airway hyperresponsive rats. Br J Pharmacol 2001; 133: 886-890.

183 Schaafsma D, Gosens R, Bos IS, Meurs H, Zaagsma J, Nelemans SA. Allergic sensitization enhances the contribution of Rho-kinase to airway smooth muscle contraction. Br J Pharmacol 2004; 143: 477-484.

184 Schaafsma D, Zuidhof AB, Nelemans SA, Zaagsma J, Meurs H. Inhibition of Rho-kinase normalizes nonspecific hyperresponsiveness in passively sensitized airway smooth muscle preparations. Eur J Pharmacol 2006; 531: 145-150.

185 Chiba Y, Murata M, Ushikubo H, et al. Effect of cigarette smoke exposure in vivo on bronchial smooth muscle contractility in vitro in rats. Am J Respir Cell Mol Biol 2005; 33: 574-581.

186 Schaafsma D, Bos IS, Zuidhof AB, Zaagsma J, Meurs H. Inhalation of the Rho-kinase inhibitor Y-27632 reverses allergen-induced airway hyperresponsiveness after the early and late asthmatic reaction. Respir Res 2006; 7: 121. 
187 Dunnill MS, Massarella GR, Anderson JA. A comparison of the quantitative anatomy of the bronchi in normal subjects, in status asthmaticus, in chronic bronchitis, and in emphysema. Thorax 1969; 24: 176-179.

188 Benayoun L, Druilhe A, Dombret MC, Aubier M, Pretolani M. Airway structural alterations selectively associated with severe asthma. Am J Respir Crit Care Med 2003; 167: 1360-1368.

189 Ebina M, Takahashi T, Chiba T, Motomiya M. Cellular hypertrophy and hyperplasia of airway smooth muscles underlying bronchial asthma. A 3-D morphometric study. Am Rev Respir Dis 1993; 148: 720-726.

190 Woodruff PG, Dolganov GM, Ferrando RE, et al. Hyperplasia of smooth muscle in mild to moderate asthma without changes in cell size or gene expression. Am J Respir Crit Care Med 2004; 169: 1001-1006.

191 Bai TR, Cooper J, Koelmeyer T, Pare PD, Weir TD. The effect of age and duration of disease on airway structure in fatal asthma. Am J Respir Crit Care Med 2000; 162: 663-669.

192 Stewart AG. Airway wall remodelling and hyperresponsiveness: modelling remodelling in vitro and in vivo. Pulm Pharmacol Ther 2001; 14: 255-265.

193 Johnson PR, Burgess JK, Underwood PA, et al. Extracellular matrix proteins modulate asthmatic airway smooth muscle cell proliferation via an autocrine mechanism. J Allergy Clin Immunol 2004; 113: 690-696.

194 Roth M, Johnson PR, Borger $\mathrm{P}$, et al. Dysfunctional interaction of $\mathrm{C} / \mathrm{EBP} \alpha$ and the glucocorticoid receptor in asthmatic bronchial smooth-muscle cells. $N$ Engl J Med 2004; 351: 560-574.

195 Schmidt D, Ruehlmann E, Branscheid D, Magnussen H, Rabe KF. Passive sensitization of human airways increases responsiveness to leukotriene $\mathrm{C}_{4}$. Eur Respir J 1999; 14: 315-319.

196 Schmidt D, Watson N, Ruehlmann E, Magnussen H, Rabe KF. Serum immunoglobulin E levels predict human airway reactivity in vitro. Clin Exp Allergy 2000; 30: 233-241.

197 Antonissen LA, Mitchell RW, Kroeger EA, Kepron W, Tse KS, Stephens NL. Mechanical alterations of airway smooth muscle in a canine asthmatic model. J Appl Physiol 1979; 46: 681-687.

198 Jiang H, Stephens NL. Isotonic relaxation of sensitized bronchial smooth muscle. Am J Physiol 1992; 262: L344L350.

199 Jiang H, Rao K, Halayko AJ, Liu X, Stephens NL. Ragweed sensitization-induced increase of myosin light chain kinase content in canine airway smooth muscle. Am J Respir Cell Mol Biol 1992; 7: 567-573.

200 Ammit AJ, Armour CL, Black JL. Smooth-muscle myosin light-chain kinase content is increased in human sensitized airways. Am J Respir Crit Care Med 2000; 161: 257-263.

201 Leguillette R, Lauzon AM. Molecular mechanics of smooth muscle contractile proteins in airway hyperresponsiveness and asthma. Proc Am Thorac Soc 2008; 5: 40-46.

202 Gil FR, Zitouni NB, Azoulay E, Maghni K, Lauzon AM. Smooth muscle myosin isoform expression and $\mathrm{LC}_{20}$ phosphorylation in innate rat airway hyperresponsiveness. Am J Physiol Lung Cell Mol Physiol 2006; 291: L932-L940.
203 Wang CG, Du T, Xu LJ, Martin JG. Role of leukotriene $\mathrm{D}_{4}$ in allergen-induced increases in airway smooth muscle in the rat. Am Rev Respir Dis 1993; 148: 413-417.

204 Henderson WR Jr, Tang LO, Chu SJ, et al. A role for cysteinyl leukotrienes in airway remodeling in a mouse asthma model. Am J Respir Crit Care Med 2002; 165: 108-116.

205 Henderson WR Jr, Chiang GK, Tien YT, Chi EY. Reversal of allergen-induced airway remodeling by CysLT1 receptor blockade. Am J Respir Crit Care Med 2006; 173: 718-728.

206 Panettieri RA, Tan EM, Ciocca V, Luttmann MA, Leonard TB, Hay DW. Effects of $\mathrm{LTD}_{4}$ on human airway smooth muscle cell proliferation, matrix expression, and contraction in vitro: differential sensitivity to cysteinyl leukotriene receptor antagonists. Am J Respir Cell Mol Biol 1998; 19: 453-461.

207 Ravasi S, Citro S, Viviani B, Capra V, Rovati GE. CysLT1 receptor-induced human airway smooth muscle cells proliferation requires ROS generation, EGF receptor transactivation and ERK1/2 phosphorylation. Respir Res 2006; 7: 42.

208 Bosse Y, Thompson C, McMahon S, Dubois CM, Stankova J, Rola-Pleszczynski M. Leukotriene $\mathrm{D}_{4^{-}}$ induced, epithelial cell-derived transforming growth factor $\beta 1$ in human bronchial smooth muscle cell proliferation. Clin Exp Allergy 2008; 38: 113-121.

209 Racke K, Matthiesen S. The airway cholinergic system: physiology and pharmacology. Pulm Pharmacol Ther 2004; 17: 181-198.

210 Racke K, Juergens UR, Matthiesen S. Control by cholinergic mechanisms. Eur J Pharmacol 2006; 533: 57-68.

211 Gosens R, Nelemans SA, Grootte Bromhaar MM, McKay S, Zaagsma J, Meurs H. Muscarinic $\mathrm{M}_{3}$-receptors mediate cholinergic synergism of mitogenesis in airway smooth muscle. Am J Respir Cell Mol Biol 2003; 28 : 257-262.

212 Krymskaya VP, Orsini MJ, Eszterhas AJ, et al. Mechanisms of proliferation synergy by receptor tyrosine kinase and $G$ protein-coupled receptor activation in human airway smooth muscle. Am J Respir Cell Mol Biol 2000; 23: 546-554.

213 Gosens R, Dueck G, Rector E, et al. Cooperative regulation of GSK-3 by muscarinic and PDGF receptors is associated with airway myocyte proliferation. Am J Physiol Lung Cell Mol Physiol 2007; 293: L1348-L1358.

214 Liu HW, Kassiri K, Voros A, et al. Gaq-receptor coupled signaling induces Rho-dependent transcription of smooth muscle specific genes in cultured canine airway myocytes. Am J Respir Crit Care Med 2002; 165: A670.

215 McQueen DS, Donaldson K, Bond SM, et al. Bilateral vagotomy or atropine pre-treatment reduces experimental diesel-soot induced lung inflammation. Toxicol Appl Pharmacol 2007; 219: 62-71.

216 McMillan SJ, Xanthou G, Lloyd CM. Manipulation of allergen-induced airway remodeling by treatment with anti-TGF- $\beta$ antibody: effect on the Smad signaling pathway. J Immunol 2005; 174: 5774-5780.

217 Leung SY, Niimi A, Noble A, et al. Effect of transforming growth factor- $\beta$ receptor I kinase inhibitor 2,4-disubstituted pteridine (SD-208) in chronic allergic airway 
inflammation and remodeling. J Pharmacol Exp Ther 2006; 319: 586-594.

218 Sturrock A, Huecksteadt TP, Norman K, et al. Nox4 mediates TGF- $\beta 1$-induced retinoblastoma protein phosphorylation, proliferation, and hypertrophy in human airway smooth muscle cells. Am J Physiol Lung Cell Mol Physiol 2007; 292: L1543-L1555.

219 Goldsmith AM, Bentley JK, Zhou L, et al. Transforming growth factor- $\beta$ induces airway smooth muscle hypertrophy. Am J Respir Cell Mol Biol 2006; 34: 247-254. 